DRAGAN ĐURANOVIĆ, Ph.D. ${ }^{1}$

E-mail: djuranovic@ef.uns.ac.rs

RADENKO M. MARIĆ, Ph.D. ${ }^{1}$

(Corresponding author)

E-mail: radenko.maric@ef.uns.ac.rs

DANIELA NUŠEVA, Ph.D. ${ }^{1}$

E-mail: nusevad@ef.uns.ac.rs

GORAN VUKMIROVIĆ, Ph.D. ${ }^{1}$

E-mail: vgoran@ef.uns.ac.rs

1 University of Novi Sad, Faculty of Economics in Subotica

Segedinski put 9-11, 24000 Subotica, Republic of Serbia
Human - Transport Interaction Preliminary Communication Submitted: Feb. 12, 2016 Accepted: Sep. 21, 2016

\title{
ANALYSIS OF INDICATORS OF CORPORATE RESPONSIBILITY IN ROAD FREIGHT TRANSPORT: RESULTS OF TRANSPORT COMPANIES AND FMCG RETAILERS IN SERBIA
}

\begin{abstract}
The aim of this paper is the analysis of indicators of corporate responsibility in road freight transport, with special emphasis on freight transport and delivery to Fast Moving Consumers Goods (FMCG) retailers and final consumer. The main task is to rank the importance of corporate responsibility indicators in freight transport from the perspective of the management of transport companies, as well as management of retail stores. In this context, empirical research was conducted on a sample of 124 managers of transport enterprises and 181 managers of FMCG retailers in Serbia. The results showed that the impact of indicators does not depend on the region, transport company and retail store. The indicators show a statistically significant dependence on FMCG type that is being transported. The conducted analysis and achieved results are important in practice as they show to the management of transport companies which indicators should be developed, so that customers (retailers), and thus the users of final products are satisfied. Disadvantages of the existing research and suggestions for future studies are provided in the paper.
\end{abstract}

\section{KEY WORDS}

road freight transport; retail stores; responsibility; transport; transport cost; supply chains;

\section{INTRODUCTION}

Profitability, survival on the market and business efficiency in the modern business environment require satisfaction of all partners in the supply chain within the logistic triangle: transport companies, retailers and final consumers [1]. In addition, recent studies $[2,3,4]$ show a high degree of positive correlation between road freight transport and the trade sector. The authors observe them as two closely related sectors, which are interrelated by mutual efficiency $[2,5]$. Efficient and responsible road freight transport is directly reflected on the business results of retailers, and thus, satisfaction and loyalty of the final consumer [6].

Responsibility is emphasized by the authors as one of the most important performances in the supply chain. It primarily implies a social segment and business responsibility towards customers, competitors and market. Murtič and Lisec [6] point out that timely delivery of goods, quality transport service, understanding of cultural and linguistic diversity, understanding the flow of transport, organizational and inter-organizational relations, needs and desires of the market in modern times are the key indicators of efficient and responsible business logistics management. Similar results were also confirmed by the studies done by Andersen and Skjoett-Larsen [7], Maloni and Brown [8] concluding that implementation of corporate responsibility in road freight transport and supply chains, contributes profitability and business success of transport companies, distributors and retailers, on one hand, and satisfaction of final product users, on the other hand.

Market and customers positively evaluate corporate responsibility in the transport of goods as well as in any other service sector [9]. The management of transport companies, which accepted to apply the basic indicators of corporate responsibility in all elements of the transport process, such as: transport conditions, the optimum quantity of goods to transport, load capacity of vehicles, transport operation and delivery terms [10], communicate this philosophy of responsibility in business, not only to its employees but also to business partners, suppliers and subcontractors, i.e. the market and the public at large $[11,12]$. In other words, the market i.e. retailers and final consumers recognize the responsibility in business, expressing loyalty to the services of the 
selected transport company, which positively reflects on a larger number of clients, growing market share and profitability. As highlighted by De George [9], corporate responsibility enables creation of additional value for all economic operators that participate in commercial transactions.

The need for exploring corporate responsibility in road freight transport stems from the fact that it is a growing economic activity, which according to the Statistical Yearbook of the Republic of Serbia [13] increased three times in the last decade and dominates the market with a share in the total transport of $75 \%$. On the other hand, growing tendency is found in retail sector, with a share in the total Serbian GDP of around $15 \%$ [13]. The main task in this paper is a detailed analysis of the corporate responsibility indicators in road freight transport and delivery of FMCG in the retail sector. The aim of the research is to precisely define the indicators that influence and shape corporate-responsible road freight transport from the viewpoint of the main economic entities involved in such supply chain: transport companies and FMCG retailers. Practical importance of the paper reflects in the fact that the results and conducted tests are used by the managers of transport companies, specialized in the delivery of FMCG to retailers, in order to comprehend the actual impact of the analysed indicators and shape the corporate-responsible workplace and a responsible employee that will undertake all business decisions and activities in a responsible manner towards customers (retailers), final consumers and the market. Because of such relationship, management of retail stores will show loyalty to the chosen transport company in the sense that it will be more attached and loyal to the services of that company, which will directly affect the profitability, market share and competitive strength.

The structure of the paper consists of the following units. After the introduction, the Theoretical Framework section presents the key theoretical aspects of the importance of the corporate responsibility concept, particularly regarding the transport and trade sector. Based on the literature review in the section Methodology, the basic research hypotheses are established, testing methods are presented, as well as research sample, the method of collecting data from the participants and statistical tools that will be used for data processing. The results, descriptive statistics and testing of hypotheses are presented in the section - Results. The next chapter - Discussion, clarifies in detail and analyses the influence of indicators on corporate responsibility in road freight transport. Conclusion summarizes the most important research results and provides suggestions for future research.

\section{THEORETICAL FRAMEWORK}

Recent professional literature includes a large number of studies, which indicates the importance of corporate and social responsibility in all aspects of economic activity, for companies, business partners, distributors, consumers and the public [14, 15, 16]. Corporate responsibility is a complex concept that involves the relationship of the employee to the company, market, public, but also to themselves [9]. In other words, corporate responsibility can be regarded as a conscientious and responsible relation between employees and companies and the narrow and broad business environment in which they operate [17]. According to Đjurić and Subotić [18], each company has three main dimensions of responsibility: to identify the expectations of customers, business partners and consumers; to effectively respond to changing market demands and to adequately meet the needs and desires of all participants in commercial transactions.

The attention of most authors in the field of road freight transport $[19,20,21]$, when it comes to responsibility, is aimed at improving all elements of the transport process, such as: complete preparation for transport, timely takeover of goods from the warehouse and loading, optimal quantity of goods for transport, compliance with the conditions of transport, deadlines and speed of delivery, adequate unloading and storage of goods, avoidance of damage, etc. The most sensitive segment of business responsibility in freight transport is found in the FMCG sector, because not only do retailers wait for delivery of the FMCG from the warehouse, but the quality, speed and accuracy of delivery directly impact the final consumers. This is particularly evident for transport and delivery of FMCG sub-categories, such as perishable goods and goods with specific features, for example, bread, milk and dairy products, meat and meat products, gas cylinders and lighters, flammable materials, charcoal, etc. [16]. The authors $[4,5,6]$ therefore, emphasize the importance of corporate responsibility in road freight transport because it is a complex activity that has multiple implications on all participants in the supply chain.

On the other hand, responsible transport and delivery of FMCG is recognized in the research dedicated to logistics and supply of retail stores $[7,8]$ as the minimal percentage of mistakes in delivery (in terms of quantity, product range, place and time of delivery), obligatory cargo insurance and paying the costs of damage, adequate transport costs, hygiene and proper handling especially for the transport of perishable goods, honesty and fair attitude of employees in transport companies, etc. According to the authors [9, $20,21]$, the biggest obstacle to the implementation of corporate responsibility in road freight transport is highlighting and emphasizing business interest, shortterm success and profitability of transport companies, 
thus neglecting the actual needs and wishes of business partners.

Based on the theoretical aspects of the research, the conclusion is that corporate responsibility in road transport and delivery of FMCG to retailers implies unity of indicators that have an impact on the business activities of transport companies, on the one hand, and FMCG retailers, on the other. To understand the relationship between indicators and their impact on corporate responsibility in road freight transport and delivery of FMCG, the significance of each indicator will be accurately defined and described. In this context, based on extensive analysis of existing literature [1, 3, $4,5,10,20]$, a systematic presentation of indicators is provided, noting that the mentioned indicators can be found sporadically in the reviewed literature and their effect and totality are not taken into account. The contribution of this paper lies in its systematization, analysis of effect and definition of the importance of each indicator in freight transport: (1) Speed and accuracy of delivery - implies that FMCG arrive from the central warehouse to the retailer at the appointed time and exact location of the FMCG retail store; (2) Traffic jam - this indicator includes predictable factors for more efficient transport and delivery of FMCG, such as the choice of the most suitable and quickest route. On the other hand, it also includes factors that are difficult to predict and plan, such as roadworks, traffic accidents, crowds, etc.; (3) Timely takeover of goods from the warehouse and loading - this indicator implies coordination and good communication between all partners in the supply chain, i.e. good and timely organization of acceptance of the FMCG by the employees in warehouses, and full coordination and continuous communication with employees in transport; (4) Proper handling and minimal damage of goods includes all actions for reducing the risk of damage to the FMCG during transport and delivery to the lowest possible level; (5) Condition of vehicles - represents a constant allocation for depreciation of vehicles, regular service and maintenance in order to minimize the risk of failure. This indicator refers to the interval of vehicle usage, heterogeneity of fleet, etc.; (6) Easy access to the retailer - this indicator represents a problem that significantly complicates the delivery of FMCG if the retailer's location is poorly accessible, such as: one-way and narrow streets, pedestrian zones, busy intersections, etc., and (7) Fair relationship with customers - means good and two-way communication between employees of the transport companies and FMCG retailers. Such communication should be aimed at sincere cooperation and problem-solving in order to achieve maximum satisfaction of final consumers.

When it comes to corporate responsibility of road freight transport from the standpoint of employees in FMCG retail stores, the following indicators are considered the most important: (1) Quality delivery of goods in terms of quantity, time and range of products - this indicator includes various business activities that transport companies must undertake to ensure quality and timely delivery of FMCG to retail stores; (2) Proper handling of packaging and hygiene, particularly in transport of perishable goods - implies meeting the standards (e.g.: ordinance on technical conditions for trade in goods) and the use of special vehicles (e.g.: refrigerator truck, large movable fridges, etc.) for transporting the goods in their initial state; (3) Transport cost - must be socially responsible, i.e. in line with actual market situation, competition price and the purchasing power; (4) Covered damage costs - to reduce operational risk and unplanned costs, retailers request that all costs associated with breakage and damage to the FMCG during loading, unloading and transport are borne by the transport company. As guarantee, retailers often require that transport companies have cargo insurance [21]; (5) Well-organized unloading of goods means that transport company should provide a sufficient number of people for unloading and storing goods in a professional and efficient manner; (6) IT support - retailers require that transport companies provide adequate information systems for tracking the locations of goods and means of transport, and (7) Fair business relationship - implies mutual cooperation of all parties in the transport process, which is reflected in prompt resolution of problems, complaints, changes in ways and methods of transport, etc.

When analyzing FMCG by categories (general merchandise and perishable goods and goods with specific features) in the transport and storage of perishable goods and goods with specific features, we will emphasize the following indicators: (1) Safety in transport - means that transport companies must fully comply with all safety measures, in order to minimise the general danger and the risk of adverse effects to the environment. This implies the selection of specialized vehicles for transport, loading and unloading done by qualified labour, the selection of area with adequate characteristics for storage, etc., (2) Meeting the standards - transport companies have to meet all the standards, rules and regulations for the transport of goods with specific features, such as the respect of the international ADR regulations, meeting the standards of the National Regulation of Transport of Dangerous Goods and the Transport of Dangerous Goods Act, etc., and (3) Guarantee - this indicator implies that transport companies are expected to provide some form of guarantee that the transported goods will be delivered in original condition. As a guarantee for the transport of perishable goods transport companies enclose the international ATP certificate, attests on technical terms of transport, etc.

Bearing in mind the mentioned aspects and the undeniable importance of corporate responsibility 
concept of road freight transport in the retail sector, the following research questions are posed: RQ1: What is the actual significance of the indicators on transport and delivery of goods in the Republic of Serbia? RQ2: Do the indicators depend on the region, transport companies and retailers? RQ3: Do indicators of corporate responsibility depend on the type of FMCG to be transported?

\section{METHODOLOGY}

\subsection{Hypotheses}

The main objective of the research is to rank the indicators of corporate responsibility in the road freight transport in the FMCG retail sector, based on empirical analysis of transport companies and retailers. On the basis of such a defined goal, it is necessary to perform testing whether the stated indicators depend on the subject region, transport companies, retailers and FMCG types. The following four research hypotheses are established:

H1 hypothesis reads: Indicators of corporate responsibility in road freight transport and the regions of the Republic of Serbia are independent characteristics. This hypothesis implies determination whether the differences in indicators of corporate responsibility in road freight transport, given the region where transport and delivery of FMCG are realized (Vojvodina, City of Belgrade, Central Serbia), are random or statistically significant. If the tested differences are statistically significant, then the hypothesis alternative $\mathrm{H} 1(a)$, which reads that indicators and the regions are dependent characteristics, is accepted.

$\mathrm{H} 2$ hypothesis reads: Indicators of corporate responsibility in road freight transport and transport companies in the Republic of Serbia are independent characteristics. This hypothesis implies determination whether the differences in indicators of corporate responsibility in road freight transport, given the company that provides transport and delivery of FMCG, are random or statistically significant. If the tested differences are statistically significant, then the hypothesis alternative $\mathrm{H} 2(\mathrm{a})$, which reads that indicators and transport companies are dependent characteristics, is accepted.

H3 hypothesis reads: Indicators of corporate responsibility in road freight transport and FMCG retailers in the Republic of Serbia are independent characteristics. This hypothesis implies determination whether the differences in indicators of corporate responsibility in road freight transport, given the retailer as the purchaser of specific range of products, are random or statistically significant. If the tested differences are statistically significant, then the hypothesis alternative $\mathrm{H} 3(\mathrm{a})$, which reads that indicators and retailers are dependent characteristics, is accepted.
H4 hypothesis reads: Indicators of corporate responsibility in road freight transport of goods and FMCG types in the Republic of Serbia are independent characteristics. This hypothesis implies determination whether the differences in indicators of corporate responsibility in road freight transport, given the FMCG type (general merchandise and perishable goods and goods with specific features), are random or statistically significant. In other words, whether indicators depend on the type of goods to be transported. If the tested differences are statistically significant, then the hypothesis alternative $\mathrm{H} 4(\mathrm{a})$ which reads that indicators and FMCG types are dependent characteristics, is accepted.

\subsection{Method}

The most adequate method for testing the established hypotheses is by applying F-test and P-value test [22]. To test the hypotheses by using F-test, the calculated $F$-value (Fstat.) is compared with the corresponding tabular value (Fcrit.). If the condition Fstat.<Fcrit. is met, the tested hypothesis is accepted, and it can be concluded that the observed characteristics are independent, i.e. that tested differences are random. However, if condition Fstat.>Fcrit. is met, the established hypothesis is rejected, while the alternative is accepted meaning that the tested differences are statistically significant [22].

Additional check of completed testing is carried out by P-value test. $P$-value is the minimum probability of error of the first kind for which the alternative hypothesis is being rejected. If the calculated $P$-value is less than the risk of errors $\alpha$, there is little $(P<0.05)$, moderate $(0.05<P<0.1)$ or strong $(P>0.10)$ evidence against alternative hypothesis $\mathrm{H}(\mathrm{a})$.

\subsection{Participants}

The study was conducted on a sample of two separate groups of participants that equally affect the efficiency and responsibility in road freight transport. Although corporate responsibility in road freight transport involves the unity of rail, water and road transport, the research sample included only transportation companies specializing in road transport of goods as according to data of the Statistical Yearbook of the Republic of Serbia [13] the share of road transport of goods in the total supply of FMCG retailers on the Serbian market is over 95\%. FMCG retailers are mainly located in urban areas, where it is impossible to deliver goods by rail or water. In addition, the important information that influenced the selection of the research sample was the fact that the delivered FMCG to retailers by inland waterways in 2014 was less than $3 \%$ (total inland waterways transport was 1.3 thousand tons, out of which FMCG was $30 \mathrm{t}$ ), while around $2 \%$ of FMCG was transported by rail to retailers (total 
domestic transport by railroad was 11.4 thousand tons, out of which FMCG was 200 t) [13]. Therefore, the first sample $(n=124)$ comprises managers (low $=86$ and middle level=38) of transport companies specialized in the transport of FMCG in the retail sector. The study included all age groups (20-30 yrs., 30-40 yrs., 40-50 yrs., 50-60 yrs., and 60+) and both genders (male=105 and female=19). The same number of respondents was tested in Vojvodina $(n=45)$, Belgrade region $(n=41)$ and Central-southern Serbia $(n=38)$. The second sample $(n=181)$ represents management (low $=126$ and middle level=55) in FMCG retail stores throughout the territory of the Republic of Serbia. As in the case of the first sample, the study covered all age groups (20-30 yrs., 30-40 yrs., 40-50 yrs., 50-60 yrs., and $60+$ ) and both genders (male $=95$ and female $=$ $86)$. By regions, the number of respondents is $n=65$ in Vojvodina, $n=61$ in the Belgrade region, and $n=55$ in the Central-southern Serbia. The research sample is appropriate and falls into the category of large statistical samples $(N=305)$.

\subsection{Procedure}

Data are collected in the period November 2015 January 2016. Anonymous electronic survey was used for the research purposes in the Google Form 2015 program, as well as field interviews of employees in transport companies and retail stores. After some general informative questions, the participants were asked to rank the importance of each available indicator of responsible road freight transport by using the expanded Likert scale (1 - no significance for transport, 7 - very significant for transport) [25]. Survey 1 was sent to transport companies, while Survey 2 was sent to FMCG retailers. Transport companies were provided with 200 questionnaires (rate of return $r=62 \%$ ), while FMCG retailers received 250 questionnaires (rate of return $r=72 \%$ ). The research sample covered the low - and middle-level managers (transport organizers, shift managers, loading and unloading organizers, etc.), while the top management was not included in this study due to unavailability and the fact that they are more oriented to the strategic decisions of companies. The research covered the following largest transport companies in the Republic of Serbia: Dunis $(n=12)$, MB trans $(n=18)$, Marjanović $(n=18)$, Srboexport $(n=23)$, Agrorit $(n=17)$, etc. When it comes to retail sector, employees were tested in the following retail stores chains: Idea $(n=32)$, DIS $(n=28)$, Moja Radnja $(n=22)$, Univerexport $(n=24)$, Gomex $(n=21)$, Maxi $(n=9)$, etc.

\subsection{Data analysis}

Statistical Package for business sciences, SPSS 20.0 and Microsoft Excel 2010 Data Analysis were used for testing, analysis and data grouping. Descriptive statistics was used for the presentation of research results, description and presentation of the basic characteristics of statistical data series. F-test and P-values test were used for verification of the hypotheses. Respondents' answers (ranked indicators) were used as the basis for creating a model of corporate responsibility in the road freight transport.

\section{RESULTS}

To describe the main characteristics of the research sample and provide a detailed presentation of answers, the following table summarizes the average (Mean-M) answers of the transport company managers. The tabular presentation is based on the indicators of corporate responsibility of road freight transport, the regions of the Republic of Serbia and two main categories of FMCG. The values of the most important descriptive statistical parameters (Standard Deviation-SD, Standard Error-SE) are highlighted in the text.

Table 1 shows the arithmetic mean of the average ranked value of the answers of managers in transport companies. It is evident that the highest average rank $(\mathrm{M}=6.5 ; \mathrm{SE}=0.1825 ; \mathrm{SD}=0.4472)$ on the whole territory of the Republic of Serbia is recorded for the indicator - Speed and accuracy of delivery. This indicator has the highest rank in individual regions as well (Vojv.= 6.5; Belg. = 6.5; Cen.-South. Srb. = 6.2). The respondents regard Speed and accuracy in the transport and delivery of goods as the most important indicator of corporate responsibility in road freight transport since it directly reflects the trust and loyalty of customers, i.e. retailers and final consumers. The second highest rank is assigned to the indicator - Condition of vehicles $(M=5.2 ; S E=0.3059 ; S D=0.2738)$. Slight variations are found for this indicator by regions. For example, in Vojvodina ( $\mathrm{M}=5.6$; $\mathrm{SE}=0.2026$; $\mathrm{SD}=0.5049$ ) and Central-southern Serbia $(\mathrm{M}=5.4 ; \mathrm{SE}=0.3159$; $\mathrm{SD}=0.7739)$ the indicator - Condition of vehicles is an important indicator of responsibility in road freight transport, while it is somewhat less significant in the region of Belgrade, where it holds the third rank $(\mathrm{M}=4.5$; $\mathrm{SE}=0.3525$; $\mathrm{SD}=0.8635)$. Transport companies in the Belgrade region highlight traffic jams as the second most important indicator that shapes responsibility in the sector of road transport of goods ( $M=5.6$; $\mathrm{SE}=0.2389$; $\mathrm{SD}=0.5853$ ), which is the expected result, given that this region has very busy traffic where frequent traffic jams and works on major roads significantly slow down the timely transport and delivery of goods. Traffic jams are assigned the next rank in the Republic of Serbia ( $M=4.8 ; \mathrm{SE}=0.3138$; $\mathrm{SD}=0.7687$ ). The fourth and fifth ranking positions belong to Timely takeover of goods from the warehouse and loading $(\mathrm{M}=3.9 ; \mathrm{SE}=0.1249 ; \mathrm{SD}=0.3060)$ and Proper handling and minimal damage of goods $(\mathrm{M}=3.4$; $\mathrm{SE}=0.2072$; $\mathrm{SD}=0.5076$ ) with identical average ranking by regions. 
Table 1 - Research results of the sample of transport companies

\begin{tabular}{|c|c|c|c|c|c|c|c|c|c|c|}
\hline 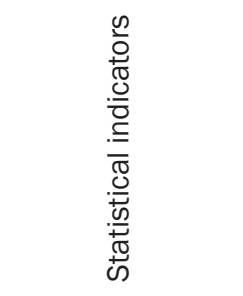 & 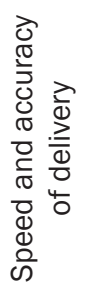 & 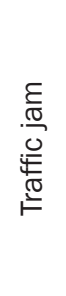 & 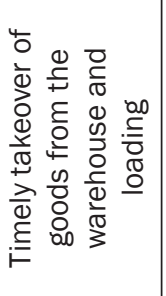 & 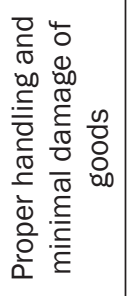 & 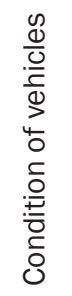 & 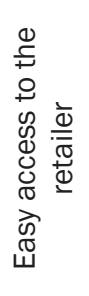 & 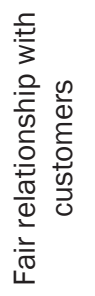 & 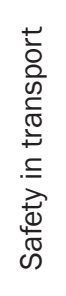 & $\begin{array}{l}00 \\
0 \\
0 \\
0 \\
0 \\
\frac{1}{0} \\
0 \\
0 \\
00 \\
0 \\
.0 \\
0 \\
0 \\
0 \\
0\end{array}$ & 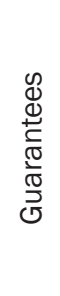 \\
\hline 1 & 2 & 3 & 4 & 5 & 6 & 7 & 8 & 9 & 10 & 11 \\
\hline \multicolumn{11}{|l|}{ Vojvodina } \\
\hline FMCG & 6.5 & 4.7 & 4 & 3.8 & 5.6 & 2.3 & 2 & 3 & 3.5 & 3 \\
\hline $\begin{array}{c}\text { General } \\
\text { Merchandise }\end{array}$ & 6.8 & 5 & 5.3 & 3.1 & 5.8 & 2.7 & 3.2 & 2 & 2.2 & 2 \\
\hline $\begin{array}{l}\text { Perishable goods } \\
\text { and goods with } \\
\text { specific features }\end{array}$ & 3 & 2.1 & 2 & 4.5 & 4 & 2 & 2 & 6.6 & 6.7 & 6.3 \\
\hline \multicolumn{11}{|l|}{ City of Belgrade } \\
\hline FMCG & 6.7 & 5.6 & 3.8 & 3 & 4.5 & 2.8 & 3.3 & 2.8 & 3.3 & 3.1 \\
\hline $\begin{array}{c}\text { General } \\
\text { Merchandise }\end{array}$ & 6.9 & 5.1 & 4.3 & 4.1 & 4.8 & 2.7 & 3.2 & 2.1 & 2.4 & 1.9 \\
\hline $\begin{array}{l}\text { Perishable goods } \\
\text { and goods with } \\
\text { specific features }\end{array}$ & 3.2 & 2.4 & 2 & 2.5 & 4.2 & 2 & 2 & 6.4 & 6.2 & 6.6 \\
\hline \multicolumn{11}{|l|}{$\begin{array}{l}\text { Central-southern } \\
\text { Serbia }\end{array}$} \\
\hline FMCG & 6.2 & 4 & 4.1 & 3.5 & 5.4 & 2 & 3.4 & 3.5 & 3 & 3.2 \\
\hline $\begin{array}{c}\text { General } \\
\text { Merchandise }\end{array}$ & 6.6 & 5.1 & 5.3 & 2.6 & 5.6 & 2.8 & 3.3 & 2.1 & 2.2 & 1.8 \\
\hline $\begin{array}{l}\text { Perishable goods } \\
\text { and goods with } \\
\text { specific features }\end{array}$ & 2.7 & 2.1 & 2 & 4.6 & 4 & 1.8 & 2 & 6.8 & 6.9 & 6.4 \\
\hline \multicolumn{11}{|l|}{ Total } \\
\hline FMCG & 6.5 & 4.8 & 3.9 & 3.6 & 5.2 & 2.4 & 2.9 & 3.1 & 3 & 3.5 \\
\hline $\begin{array}{c}\text { General } \\
\text { Merchandise }\end{array}$ & 6.8 & 5.2 & 5.4 & 3 & 5.9 & 2.9 & 3.2 & 2 & 2.2 & 3 \\
\hline $\begin{array}{l}\text { Perishable goods } \\
\text { and goods with } \\
\text { specific features }\end{array}$ & 3.2 & 2.3 & 1.8 & 4.4 & 4 & 2 & 2.1 & 6.7 & 6.6 & 6.5 \\
\hline
\end{tabular}

Source: Author's calculations

The next three positions belong to indicators such as Safety in transport $(\mathrm{M}=3.1 ; \mathrm{SE}=0.2487 ; \mathrm{SD}=0.6847)$, Meeting standards $(\mathrm{M}=3 ; \mathrm{SE}=0.3714 ; \mathrm{SD}=0.8437)$, and Guarantees ( $M=3.5 ; S E=0.4124 ; S D=0.5142)$. However, when FMCG is viewed separately by category, such as perishable goods and goods with specific features, then the stated indicators on the level of the market of the Republic of Serbia occupy the first three positions, with high average values $(\mathrm{M} 1=6.7, \mathrm{M} 2=6.6$, $M 3=6.5)$. The result leads to the conclusion that safety of the carrier, protection of the environment, the work of professionals, the existence of guarantees, the choice of vehicles with the appropriate characteristics, etc., are the most important indicators for the managers of transport companies regarding the transport of perishable goods and goods with specific features, which include perishable and non-conserved food products, flammable materials, lighters, gas cylinders, charcoal, etc. The bottom rankings are assigned to the indicators - Fair relationship with customers $(\mathrm{M}=2.9 ; \mathrm{SE}=0.3270 ; \mathrm{SD}=0.8010)$ and Easy access to the retailer $(\mathrm{M}=2.4 ; \mathrm{SE}=0.1118 ; \mathrm{SD}=0.2738)$. As in the previous methodology, Table 2 shows the results of the second testing sample - managers in FMCG retail stores. The tabular presentation is based on the indicators, regions of the Republic of Serbia and FMCG categories. 
Table 2 - Research results of the retailer sample

\begin{tabular}{|c|c|c|c|c|c|c|c|c|c|c|}
\hline 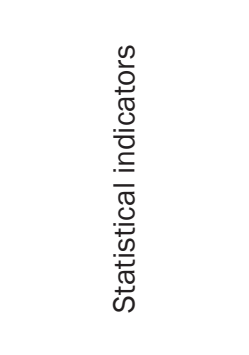 & 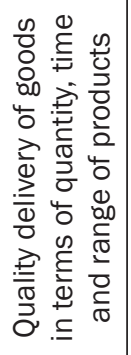 & 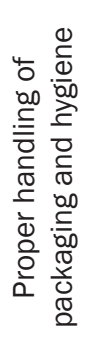 & 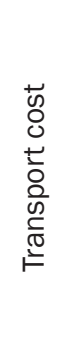 & 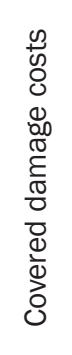 & 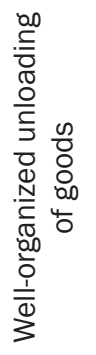 & $\begin{array}{l}\frac{1}{2} \\
\frac{0}{0} \\
\frac{0}{7} \\
\text { ヒ } \\
=\end{array}$ & 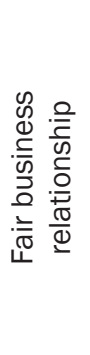 & 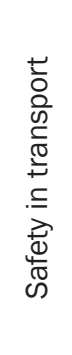 & 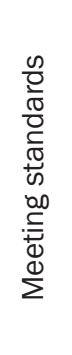 & 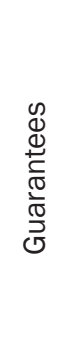 \\
\hline 1 & 2 & 3 & 4 & 5 & 6 & 7 & 8 & 9 & 10 & 11 \\
\hline \multicolumn{11}{|l|}{ Vojvodina } \\
\hline FMCG & 6.8 & 5.3 & 3 & 4 & 2.6 & 2.3 & 3 & 2.7 & 3.3 & 3.1 \\
\hline $\begin{array}{c}\text { General } \\
\text { Merchandise }\end{array}$ & 6.9 & 5.4 & 5.1 & 3.1 & 1.7 & 2.7 & 3.2 & 2 & 2.2 & 2 \\
\hline $\begin{array}{l}\text { Perishable goods } \\
\text { and goods with } \\
\text { specific features }\end{array}$ & 3.2 & 2.1 & 2 & 4.7 & 3.9 & 1,8 & 1,9 & 5 & 6.7 & 6.4 \\
\hline \multicolumn{11}{|l|}{ City of Belgrade } \\
\hline FMCG & 6.7 & 5.6 & 2.8 & 4.5 & 2.5 & 2.8 & 3.2 & 2.9 & 3.2 & 3.1 \\
\hline $\begin{array}{c}\text { General } \\
\text { Merchandise }\end{array}$ & 6.9 & 5.1 & 4.4 & 4.2 & 2.1 & 2.7 & 3.2 & 2.2 & 2.5 & 1.8 \\
\hline $\begin{array}{l}\text { Perishable goods } \\
\text { and goods with } \\
\text { specific features }\end{array}$ & 3.3 & 2.3 & 2.1 & 2.5 & 3 & 2 & 2 & 4.9 & 6.2 & 6.5 \\
\hline \multicolumn{11}{|l|}{$\begin{array}{c}\text { Central-southern } \\
\text { Serbia }\end{array}$} \\
\hline FMCG & 6.2 & 4 & 4.1 & 3.5 & 2 & 2 & 3.4 & 3.3 & 2.8 & 3.2 \\
\hline $\begin{array}{c}\text { General } \\
\text { Merchandise }\end{array}$ & 6.7 & 5.3 & 5.3 & 2.6 & 1.6 & 2.8 & 3.2 & 2.2 & 2.3 & 1.7 \\
\hline $\begin{array}{l}\text { Perishable goods } \\
\text { and goods with } \\
\text { specific features }\end{array}$ & 2.4 & 2.1 & 1.9 & 4.2 & 3,9 & 1.8 & 2 & 5 & 6.8 & 6.2 \\
\hline \multicolumn{11}{|l|}{ Total } \\
\hline FMCG & 6.6 & 5 & 3.3 & 4 & 2.4 & 2.4 & 3.2 & 3 & 3 & 3.2 \\
\hline $\begin{array}{c}\text { General } \\
\text { Merchandise }\end{array}$ & 6.8 & 5.2 & 4.5 & 3 & 1.9 & 2.9 & 3.2 & 2 & 2.1 & 3.2 \\
\hline $\begin{array}{l}\text { Perishable goods } \\
\text { and goods with } \\
\text { specific features }\end{array}$ & 3.2 & 2.3 & 1.8 & 4.4 & 3.8 & 2 & 2.1 & 5 & 6.6 & 6.5 \\
\hline
\end{tabular}

Source: Author's calculations

The managers of retail stores assign the highest average ranking, at the level of entire sample, to quality delivery of goods in terms of quantity, time and product range $(\mathrm{M}=6.6$; $\mathrm{SE}=0.2020 ; \mathrm{SD}=0.5345)$. This indicator of corporate responsibility in transport of goods dominates in all regions, on average by one rank above other indicators. The results confirm previous research dedicated to logistics management $[7,8]$, and highlight accurate, timely and quality delivery of the goods in terms of quantity, product range, place and time of delivery as the most important tasks in the supply chain. The following ranked indicator of road freight transport is Proper handling of packaging and hygiene
$(M=5 ; S E=0.3086 ; S D=0.8165)$. It is evident that the indicator - Handling of packaging has a higher average ranking in Vojvodina $(M=5.3 ; S E=0.2458$; $\mathrm{SD}=0.6503)$ and the Belgrade region $(\mathrm{M}=5.6$; $\mathrm{SE}=0.2458$; $\mathrm{SD}=0.6576$ ), while it holds third place in the region of Central and Southern Serbia $(M=4$; $\mathrm{SE}=0.2849$; $\mathrm{SD}=0.7537)$, behind the indicator Transport cost $(\mathrm{M}=4.1$; $\mathrm{SE}=0.2369 ; \mathrm{SD}=0.6268)$. Such result in Central-southern Serbia is expected because it is a less economically developed area of the Republic of Serbia [13] and therefore emphasizes the importance of having a socially responsible and commercially realistic transport cost. 
In the total sample, the third place belongs to the indicator - Covered damage cost $(\mathrm{M}=4$; $\mathrm{SE}=0.4364$; $S D=1.1547$ ), where retailers require that vehicles must have obligatory cargo insurance for the goods transported. Slightly less importance is given to Fair business relationship ( $\mathrm{M}=3.2 ; \mathrm{SE}=0.2641 ; \mathrm{SD}=0.6986)$. Similar to the sample of transport companies, the indicators - Safety $(\mathrm{M}=3 ; \mathrm{SE}=0.2147 ; \mathrm{SD}=0.6332)$, Meeting standards $(\mathrm{M}=3 ; \mathrm{SE}=0.2232 ; \mathrm{SD}=0.5874)$ and Guarantees ( $M=3.2 ; \mathrm{SE}=0.3028 ; \mathrm{SD}=0.5989)$ occupy the central place in terms of importance to corporate responsibility, while the same indicators hold the first three positions if the analysis of FMCG is done by categories. The difference compared to the first sample lies in the fact that retailer managers value the respect of standards $(M=6.6)$ and the guarantees that the goods with specific features will be delivered unaltered $(M=6.5)$, more than the issues related to the safe transport of goods $(\mathrm{M}=5)$. Bottom average ranks are assigned to the organization of unloading $(\mathrm{M}=2.4$; $\mathrm{SE}=0.4185 ; \mathrm{SD}=1.1073)$ and IT support $(\mathrm{M}=2.4$; $\mathrm{SE}=0.3168 ; \mathrm{SD}=0.8381$ ). Low ranking of IT support is surprising as it enables accurate location of goods at any moment, but it leads to conclusion that there is no satisfactory IT support and computer literacy of retailers, which requires substantive allocation of funds for their implementation and IT training.

Established hypotheses are checked by statistical and parametric F-test and P-value test. Conclusions on acceptance or rejection of the established hypotheses are made based on the risk of error $\alpha=0.05$ and $\alpha=0.01$. Hypotheses are tested on independence of indicators on socially responsible road freight transport of goods and the regions of the Republic of Serbia separately for each of the samples.

Table 3 provides basic information and the value of $F$ statistics necessary for testing $\mathrm{H} 1$ hypothesis on $\mathrm{a}$ sample of transport companies.

Table 3 - Testing hypothesis H1 - sample of transport companies

\begin{tabular}{||c|c|c|c||}
\hline Fstat. & P-value & \multicolumn{2}{|c|}{ Fcrit. $_{(\alpha=0.01 ; \alpha=0.05)}$} \\
\hline \hline .0168 & .9833 & 6.0129 & .5546 \\
\hline
\end{tabular}

Source: Author's calculations

Given that Fstat. $=0.0168<$ Fcrit. $=6.0129$, Table 3, shows that with the risk of error of $1 \%$, hypothesis $\mathrm{H} 1$ is accepted, while alternative hypotheses $\mathrm{H} 1(\mathrm{a})$ is rejected. In addition, the second testing condition is met, given that Fstat. $=0.0168<$ Fcrit. $=3.5546$, so it is found that with the risk of error of $5 \%, \mathrm{H} 1$ hypothesis is accepted. The conclusion on acceptance of $\mathrm{H} 1$ is further confirmed by calculated $P$-value, which shows strong evidence against alternative hypothesis $\mathrm{H} 1$ (a) given that $P=0.9833>0.1000$. The identical testing will be performed on the second research sample of FMCG retailers - Table 4.

Table 4 - Testing hypothesis H1 - FMCG retailers sample

\begin{tabular}{|c|c|c|c||}
\hline \hline Fstat. & P-value & \multicolumn{2}{|c|}{ Frit. $_{(\alpha=0.01 ; \alpha=0.05)}$} \\
\hline \hline .1240 & .8841 & 6.0129 & 3.5546 \\
\hline
\end{tabular}

Source: Author's calculations

The results of F-test on the sample of FMCG retail stores show that $\mathrm{H} 1$ is accepted, given that Fstat. $=0.1240<$ Fcrit. $=6.0129$, for $\alpha=0.01$, i.e. Fstat. $=0.1240<$ Fcrit. $=3.5546$ for $\alpha=0.05$. such results are provided by $P$-value, where $P=0.8841>0.1000$. The obtained results show that the first hypothesis $\mathrm{H} 1$ on the independence of indicators of corporate responsibility in road freight transport and the region of the Republic of Serbia is accepted, for both research samples. It means that the differences in the indicators of responsibility with regard to the subject region are random, i.e. unique to the entire market of the Republic of Serbia.

In the next step, second hypothesis $\mathrm{H} 2$ is tested on the independence of indicators of corporate responsibility in transport of FMCG and transport companies. $\mathrm{H} 2$ hypothesis is tested for each region of the Republic of Serbia. The necessary data are illustrated by the following Table 5.

Table 5 - Testing hypothesis $\mathrm{H} 2$ - transport companies

\begin{tabular}{||c|c|c|c|c||}
\hline \hline Region & Fstat. & P-value & \multicolumn{2}{|c||}{ Fcrit. $_{(\alpha=0.01 ; \alpha=0.05)}$} \\
\hline \hline Vojvodina & .1125 & .9889 & 3.5744 & 2.4771 \\
\hline Belgrade & .1419 & .9812 & 3.5744 & 2.4771 \\
\hline $\begin{array}{c}\text { Central- } \\
\text {-southern } \\
\text { Serbia }\end{array}$ & .2699 & 9266 & 3.5744 & 2.4771 \\
\hline $\begin{array}{c}\text { Total } \\
\text { - Serbia }\end{array}$ & .1857 & .9662 & 3.5744 & 2.4771 \\
\hline
\end{tabular}

Source: Author's calculations

Table 5 shows that in every region and at the level of the entire market, the condition Fstat.<Fcrit. is met, which means that in every region $\mathrm{H} 2$ hypothesis is accepted, while the alternative hypothesis $\mathrm{H} 2(\mathrm{a})$ is rejected. The same conclusion is made on the basis of the P-value test, given that in all regions the condition of strong evidence is met against $\mathrm{H} 2(\mathrm{a})$, since $P>0.1000$. Conducted testing confirms that the corporate responsibility indicators of road freight transport are independent from transport companies, i.e. the difference between the tested indicators are random with respect to transport companies. This implies that the indicators on corporate responsibility in transport of goods may be common to all transport companies on the Serbian market. 
The next step is testing the third research hypothesis $\mathrm{H} 3$ on the independence of indicator of corporate responsibility in freight transport and FMCG retail stores. The test results are shown in Table 6.

Table 6 - Testing hypothesis H3 - FMCG retailers

\begin{tabular}{||c|c|c|c|c||}
\hline Region & Fstat. & $P$-value & \multicolumn{2}{|c|}{ Fcrit. $_{(\alpha=0.01 ; \alpha=0.05)}$} \\
\hline \hline Vojvodina & 1692 & .9836 & 3.2658 & 2.3239 \\
\hline Belgrade & .0974 & .9963 & 3.2658 & 2.3239 \\
\hline $\begin{array}{c}\text { Central- } \\
\text {-southern } \\
\text { Serbia }\end{array}$ & .3166 & .9247 & 3.2658 & 2.3239 \\
\hline $\begin{array}{c}\text { Total } \\
\text { - Serbia }\end{array}$ & .1178 & .9937 & 3.2658 & 2.3239 \\
\hline
\end{tabular}

Source: Author's calculations

The results, as in the case of transport companies, confirm the condition Fstat.<Fcrit., for each tested region. Identical results are found by $P$-value, where $P>0.1000$. As result of the conducted testing, hypothesis H3 is accepted, which means that the differences in the indicators of the corporate responsibility in freight transport, with respect to retail stores as their partners in the supply chain, are random. In other words, the above indicators of responsibility in the transport of goods can be common for all retailers on the market of the Republic of Serbia.

The final step in the testing process is testing of $\mathrm{H} 4$ hypothesis on independence of corporate responsibility indicators and FMCG types to be transported. Necessary data for both research samples, observed by FMCG category, at the level of the entire market of the Republic of Serbia, is illustrated by the following table (Table 7).

Conducted testing shows that hypothesis $\mathrm{H} 4$ is rejected for FMCG type - perishable goods and goods with specific features, because the requirements Fstat. $>$ Fcrit. and $P<0.10$ are met. This hypothesis is rejected when tested on both research samples, which suggests that indicators of corporate responsibility in road freight transport depend on the type of FMCG, especially the categories of perishable goods and goods with specific features. For the other category of FMCG - General Merchandise, there is no statistically significant correlation.

\section{DISCUSSION}

Based on the obtained results, the respondents' answers, and performed testing of the hypotheses, it can be concluded that the indicators of corporate responsibility in road freight transport are unique for the entire market of the Republic of Serbia and independent of the region, transport company and retailer, while the dependence is observed only for the type of FMCG to be transported, especially for perishable goods and goods with specific features. This conclusion provides the ability to create three charts that will serve as the basis for discussion and analysis of the results. The first schematic presentation (SP1) includes transport companies, the second schematic presentation (SP2) refers to retailers, while the third schematic presentation (SP3) is a fusion of the two previous presentations. The indicators are specifically grouped into two basic categories of FMCG. The indicators in schematic presentations were ranked according to the respondents' answers, on a scale from 1 - insignificant influence to 7 - significant influence. The first schematic presentation SP1 is shown in Figure 1.

Speed and accuracy of...

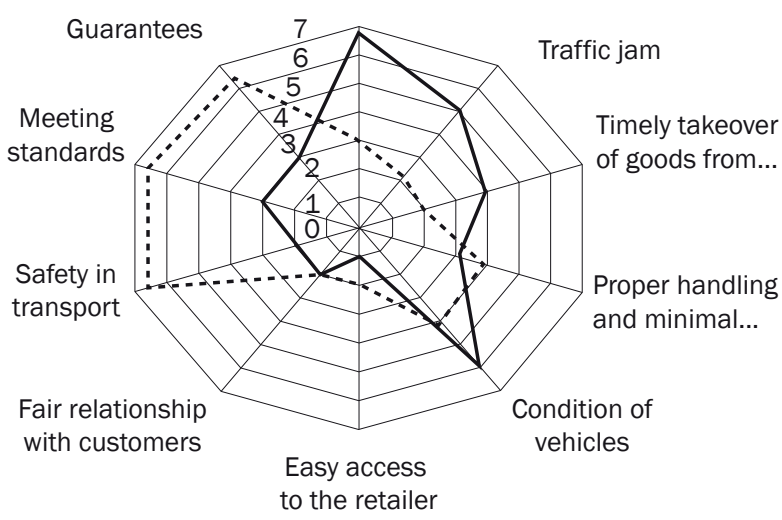

General Merchandise

Perishable goods and goods with specific features

Figure 1 - SP1 - Schematic presentation of corporate responsibility in road freight transport (transport companies)

Table 7 - Testing hypothesis H4 - FMCG types

\begin{tabular}{|c|c|c|c|c|}
\hline \multirow{2}{*}{$\begin{array}{l}\text { FMCG types } \\
\text { Sample of transport companies }\end{array}$} & \multirow[t]{2}{*}{ Fstat. } & \multirow[t]{2}{*}{$P$-value } & \multicolumn{2}{|c|}{ Fcrit. $_{(\alpha=0.01 ; \alpha=0.05)}$} \\
\hline & & & & \\
\hline General Merchandise & .0049 & .9951 & 5.4881 & 3.3541 \\
\hline Perishable goods and goods with specific features & $6.025 * *$ & .0785 & 5.4881 & 3.3541 \\
\hline Sample of FMCG retailers & & & & \\
\hline General Merchandise & .0167 & .9837 & 5.4881 & 3.3541 \\
\hline Perishable goods and goods with specific features & $5.352 *$ & .0654 & 5.4881 & 3.3541 \\
\hline
\end{tabular}


The most important indicator of corporate responsibility in General Merchandise for the management and the business interest of transport companies is the speed and accuracy of delivery (rank 7 ). This result agrees with the results of related research $[7,8$, 15] implying that accuracy and speed of transport and delivery are the most important factors of a good business relationship in the entire logistics supply chain. Great importance (rank 6) belongs to the indicator Condition of vehicles, since without timely investment in transport means it is impossible to achieve a reliable and quality transport. Transport companies answered that indicators that hamper corporate responsibility are the unplanned problems and traffic jams (rank 5), as well as good organization of loading and takeover of goods by employees in the central warehouse (rank 4). Slightly less important (rank 3) indicators are Proper handling and minimal damage of goods and Fair relationship with customers (rank 2). Finally, location of retailer had almost no influence (rank 1). Compared to General Merchandise, categories of perishable goods and goods with specific features indicate the greatest differences for indicators of Safety and Meeting standards (rank 7) and Guarantees (rank 6). These three indicators are seen as crucial by the management of transport companies when it comes to the transport of goods with specific features on the territory of the Republic of Serbia. The results are consistent with some previous studies $[4,15,19,20]$ that emphasize the importance of safety and respect of standards in transport of FMCG. Condition of vehicles and Proper handling and minimal damage of goods occupy rank 4 , while other indicators are less important to corporate responsibility. Figure 2 illustrates the Schematic presentation of SP2.

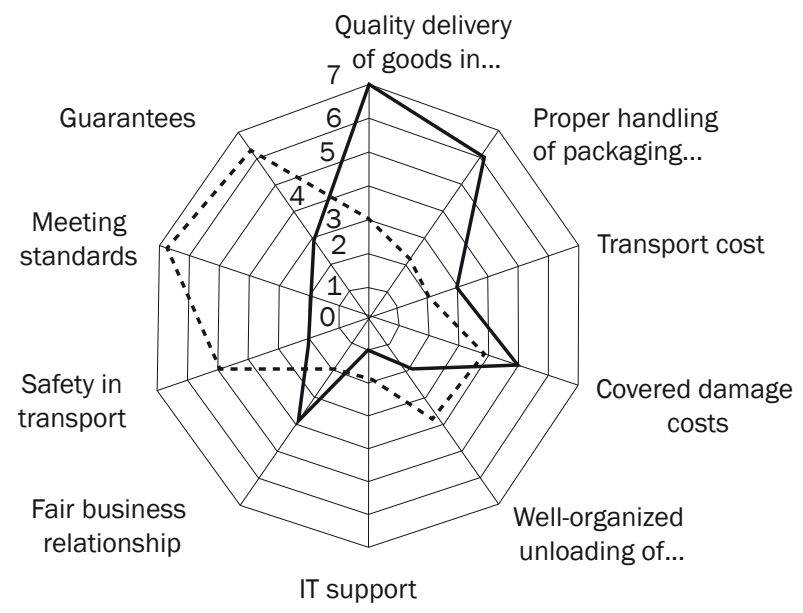

General Merchandise

Perishable goods and goods with specific features

Figure 2 - SP2 - Schematic presentation of corporate responsibility in road freight transport (FMCG retailers)
Retailers highlight quality delivery from the standpoint of quantity, time and product range (rank 7) as the most important indicator of responsibility in the transport of FMCG. Any deviation and error in a subject indicator reflects on customers, consumers and the market, and greatly affects the image of the retailer in public. The next two indicators are interlinked and relate to minimizing unplanned expenses for transport and delivery of goods. These are Proper handling of packaging and hygiene (rank 6) and Covered damage costs (rank 5). Retailers require a completely safe transport of goods and a common instrument of security such as cargo insurance for the transported goods. Great significance in retail industry is attached to fair relations and good cooperation with the employees of transport companies (rank 4). These results are consistent with similar studies $[8,14]$ that emphasize honesty and fairness as an important determinant of social and corporate responsibility in the service sector. Transport cost and Guarantees hold the fifth place (rank 3) and dominate in the least developed regions of Central-southern Serbia. Little significance to responsibility in transport is attached to good organization of goods unloading, safety and meeting standards (rank 2), while the bottom rank is assigned to IT support (rank 1) due to large financial investment and under-developed market not being able to accept information business. On the other hand, the most important thing for retailers in transport of perishable goods and goods with specific features is to receive them in original state, and therefore the highest ranks belong to indicators of Meeting standards (rank 7) and Guarantees (rank 6). Retailers attach less importance to Safety issues in transportation (rank 5) because they are not familiar with the technology of transport, the risk in transport of such goods, etc. The schematic presentation of $\mathrm{SP}_{3}$ (Figure 3) shows the cross-section of these indicators.

Schematic presentation of $\mathrm{SP}_{3}$ is the result of market research between employees in the transport and retail sector, and as such it provides a fair presentation of the indicators important for achieving greater corporate responsibility in road transport and delivery of FMCG to retailers of the Republic of Serbia. This presentation should be a general binding standard for every transport company specialized in transport and delivery of FMCG in the retail sector. The comparison of the obtained results reveals the most important indicators - Quality, accurate and timely delivery of required goods, Standards and Safety (rank 7), Proper handling of the packaging during transport and loading, Condition of vehicles and Guarantees (rank 6). They are followed by Traffic jams and Covered costs of damage to packaging (rank 5). Next rank (rank 4) is assigned to Timely and well-organized collection of goods from the warehouse and Fairness and honesty in business relations. Slightly less significance 


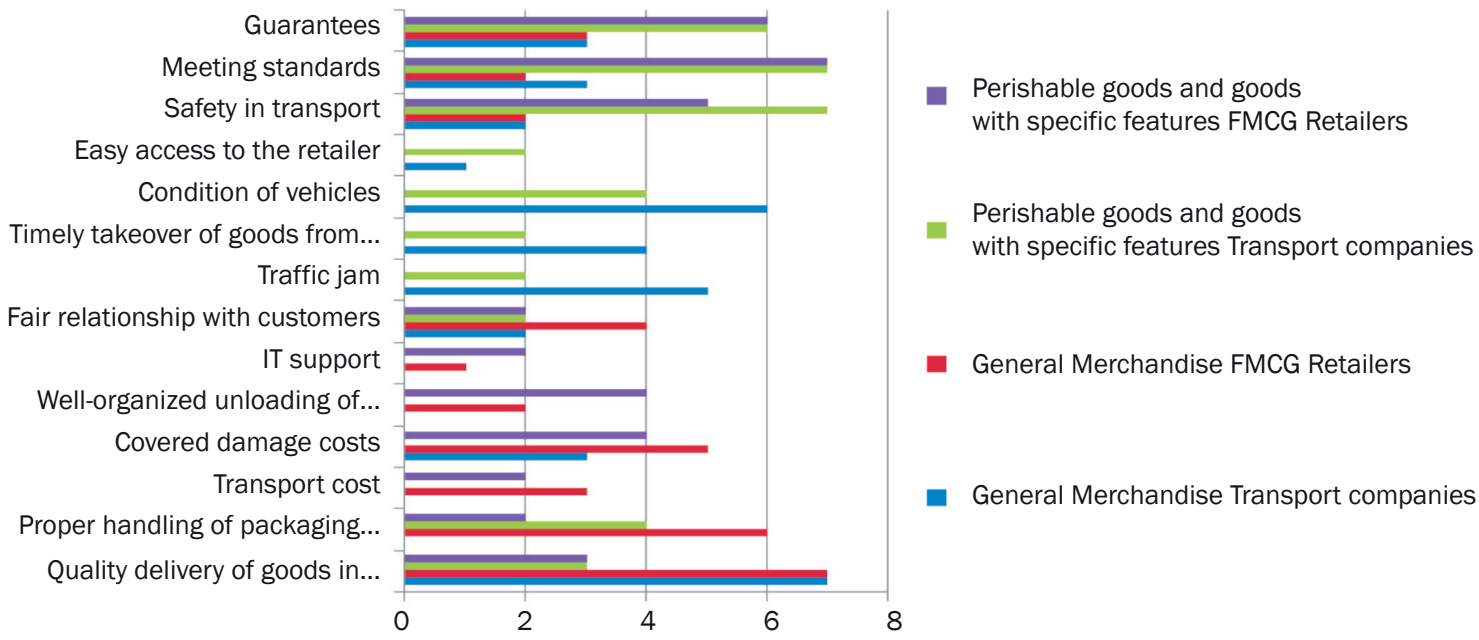

Figure 3 - SP3 - Schematic presentation of corporate responsibility in road freight transport in the FMCG retail sector

(rank 3) is assigned to Transport cost. Minimal impact is expressed by Good organization of goods unloading, IT support and Easy access to retailers.

\section{CONCLUSION}

The need for study on responsibility in road freight transport in the FMCG retail sector stems from the fact that it is a growing economic activity with a significant share in the total GDP of the Republic of Serbia and a large number of business partners, where their business outcome and survival on the market are interdependent. In order to conduct the analysis of corporate responsibility in road freight transport, an empirical study was carried out that included employees of transport companies and FMCG retail stores.

The importance of each indicator on corporate responsibility is ranked by managers in the transport and FMCG retail sector. Testing confirmed the established hypotheses and provided answers to the research questions that differences in the indicators with regard to region, transport companies and retailers are random, while significant differences are found among the indicators depending on the type of FMCG to be transported. The entire Serbian market can be seen as a unit, which enables constructing the chart with clearly assigned significance rank to each indicator on corporate responsibility in road transport of FMCG (Figure 1, Figure 2 and Figure 3). Such schematic presentation should be the basic standard of business conduct in transport companies in order to achieve economic efficiency, profitability and competitiveness of all the partners in the supply chain. It is necessary to create such a business climate in the transport of FMCG in order to clearly define and favour indicators, to reward their compliance and acceptance, and sanction any failure to do so. Such transport companies will be recognized by the public, consumers and the market as socially responsible businesses, which will result in satisfied and loyal customers.

The disadvantage of conducted research is a limitation to the market of the Republic of Serbia. It reflects the actual situation of the Western Balkans, but it is necessary to expand the research and make a comparison with EU member states. In addition, future research should focus on: (1) the analysis of impact of subgroups within the offered indicators, such as: within the indicator Condition of fleet there should be separate ranking of heterogeneity of fleet, period of engagement, the possibility of using one vehicle several times a day, etc., (2) a more detailed analysis by types of FMCG within the given categories, for example: specific analyses of bakery products, milk, frozen fruits and vegetables, etc.

Doc. dr DRAGAN ĐURANOVIĆ ${ }^{1}$

E-mail: djuranovic@ef.uns.ac.rs

Doc. dr RADENKO M. MARIĆ ${ }^{1}$

E-mail: radenko.maric@ef.uns.ac.rs

Dr DANIELA NUŠEVA ${ }^{1}$

E-mail: nusevad@ef.uns.ac.rs

Doc. dr GORAN VUKMIROVIĆ ${ }^{1}$

E-mail: vgoran@ef.uns.ac.rs

1 Univerzitet u Novom Sadu, Ekonomski fakultet u Subotici

Segedinski put 9-11, 24000 Subotica, Republika Srbija

\section{REZIME}

\section{ANALIZA INDIKATORA POSLOVNE ODGOVORNO- STI U CESTOVNOM PRIJEVOZU ROBE: REZULTATI ISTRAŽIVANJA TRANSPORTNIH PODUZEĆA I FMCG MALOPRODAJNIH OBJEKATA U SRBIJI}

Cilj ovog rada je da se izvrši analiza indikatora poslovne odgovornosti u cestovnom transportu robe, s posebnim osvrtom na transport $i$ isporuku robe široke potrošnje (FMCG) maloprodajnim objektima i finalnom potrošaču. Osnovni zadatak je da se rangira značaj indikatora poslovne 
odgovornosti u transportu robe promatrano iz kuta menadžmenta transportnih poduzeća, kao i menadžmenta maloprodajnih objekata. U tom kontekstu, provedeno je empirijsko istraživanje na uzorku od 124 menadžera transportnih poduzeća i 181 menadžera FMCG maloprodajnih objekata u Republici Srbiji. Rezultati istraživanja su pokazali da je utjecaj indikatora neovisan o regiji, transportnog poduzeća i maloprodajnog objekta. Indikatori pokazuju statistički značajnu ovisnost od vrste FMCG koja je predmet transporta. Sprovedena analiza i dobijeni rezultati imaju značaj u praksi jer pokazuju menadžmentu transportnih poduzeća koje indikatore treba razvijati, kako bi klijenti (maloprodajni objekti), a time i korisnici finalnih proizvoda bili zadovoljni. Nedostaci postojećeg istraživanja i prijedlozi za buduća istraživanja navedeni su u radu.

\section{KLUUČNE REČI}

cestovni prijevoz robe; lanci opskrbe; maloprodajni objekti; odgovornost; transport; troškovi transporta;

\section{REFERENCES}

[1] Kač SM, Gorenak I, Potočan V. Influence of Relationship Commitment and Trust on Collaborative Behaviour in Supply Chains. Promet - Traffic \& Transportation. 2015;27(1):77-84. doi: 10.7307/ptt.v27i1.1575.

[2] Storeygard A. Farther on Down the Road: Transport Costs, Trade and Urban Growth in Sub-Saharan Africa. World Bank Policy Research Working Paper. 2013;6444:1-55.

[3] Verhoef E, Nijkamp P, Rietveld R. The trade-off between efficiency, effectiveness, and social feasibility of regulating road transport externalities. Transportation Planning and Technology. 1996;19(3-4):247-263. doi: 10.1080/03081069608717572.

[4] Holl A. Manufacturing location and impacts of road transport infrastructure: empirical evidence from Spain. Regional Science and Urban Economics. 2004;34(3):341-363. doi: 10.1016/S01660462(03)00059-0.

[5] Francois JF, Wooton I. Trade in International Transport Services: The Role of Competition. CIES Working Paper. 2000;4:1-26. doi: 10.2139/ssrn.231238.

[6] Murtič S, Lisec A. Models of Inter-Organizational Logistics Management in Slovenia. PROMET - Traffic\&Transportation. 2015;27(1):97-104. doi: 10.7307/ptt. v27i1.1320

[7] Andersen M, Skjoett-Larsen T. Corporate social responsibility in global supply chains. Supply Chain Management: An International Journal. 2009;14(2):75-86. doi: 10.1108/13598540910941948.

[8] Maloni M, Brown M. Corporate Social Responsibility in the Supply Chain: An Application in the Food Industry.
Journal of Business Ethics. 2006;68(1):35-52. doi: 10.1007/s10551-006-9038-0.

[9] De George RT. [Poslovna etika]. Belgrade: Filip Višnjić Ip; 2003. English

[10] Jusufranić I. Osnove drumskog transporta - tehnologija - organizacija - ekonomika - logistika - upravljanje. Travnik: Saobraćajni fakultet; 2007. Bosnian

[11] McWilliams A, Siegel D. Corporate social responsibility: a theory of the firm perspective. Academy of Management Review. 2001;26(1):117-127. doi: 10. 5465/ AMR.2001.4011987.

[12] Garriga E, Mele D. Corporate Social Responsibility Theories: Mapping the Territory. In: Poff DC, Michalos AC, editors. Advances in Business Ethics Research, Springer Netherlands; 2012. p. 69-96.

[13] [Statistical Yearbook of Republic of Serbia]. Beograd: Zavod za statistiku Republike Srbije; 2014. Serbian

[14] Berber N, Šušnjar GS, Slavić A, Baošić M. Relationship between Corporate Social Responsibility and Human Resource Management - as new management concepts - in Central and Eastern Europe. Engineering Economics. 2014;25(3):360-369. doi: 10.5755/j01. ee.25.3.4222.

[15] Besley T, Ghatak M. Retailing Public Goods: The Economics of Corporate Social Responsibility. Journal of Public Economics. 2007;91(9):1645-1663. doi: 10.1016/j.jpubeco.2007.07.006.

[16] BanejreeSB. CorporateSocial Responsibility:The Good, the Badand the Ugly. CritSociol January. 2008;34(1):5179. doi: $10.1177 / 0896920507084623$.

[17] Radun V, Đurić R, Kostadinović-Krasić D. Using Competitive Intelligence in Assessing CSR as Competitiveness Factor in Financial Sector. Anali Ekonomskog fakulteta u Subotici. 2013;49(29):273-291.

[18] Đurić Ž, Subotić D. Poslovna etika (in Serbian) (Eng. Business Ethics). Belgrade: Institute for Political Studies; 2005.

[19] Kreutzberger ED. Distance and time in intermodal goods transport networks in Europe: A generic approach. Transportation Research Part A: Policy and Practice. 2008;42(7):973-993. doi: 10.1016/j. tra.2008.01.012.

[20] Dablanc L. Goods transport in large European cities: Difficult to organize, difficult to modernize. Transportation Research Part A: Policy and Practice. 2007;41(3):280285. doi: 10.1016/j.tra.2006.05.005.

[21] Van Schijndel WJ, Dinwoodie J. Congestion and multimodal transport: a survey of cargo transport operators in the Netherlands. Transport Policy. 2000;7(4):231241. doi: 10.1016/S0967-070X(00)00023-8.

[22] Sullivan M. Statistics: Informed Decisions Using Data. New Jersey: Prentice Hall; 2007. 